\title{
Inheritance of a New Albino Mutation in Brazilian Free-range Black Chickens
}

\section{Author(s)}

Jorge $W$

Cunha LM ${ }^{1}$

Departamento de Biologia Geral. Instituto de Ciências Biológicas. Universidade Federal de Minas Gerais, Belo Horizonte.

\section{Mail Address}

\section{W Jorge}

Rua Carrara, 111

Bairro Bandeirantes

31.340-710. Belo Horizonte, MG, Brasil.

E-mail: wiljorge@icb.ufmg.br

\section{Keywords}

Albinism, chicken, inheritance, melanin.

This study was funded by FAPESP.

\section{ABSTRACT}

A genetically recessive albino mutation, which inhibits pigment development in the eyes, skin, and feathers of domestic chickens from Brazil, is described. This mutation appeared in a flock of completely black chickens of a private breeder. There are no information on the origin, breed, or specific line of the birds. Pigment inhibition is apparently complete in the feathers and eyes. Bird sight is very impaired, but no histological examination was carried out. Ratios obtained in F2 and backcrossed birds indicate that a single autosomal recessive gene is responsible for the condition. The data suggest that the absence of melanin in the eyes, skin, and feathers (symbol cc) is a mutation of the pigmented $\mathrm{C}$ wild gene.

\section{INTRODUCTION}

The term "albinism" comprises a wide range of traits, all of which result from pigment production or distribution disorders. The phenotype is due to a defect in melanin synthesis that results in partial or complete absence of this pigment in the skin, hair, feather, and eyes. The trait can be inherited by autosomal (recessive or dominant) or Z-linked (Xlinked in mammals) inheritance. Several different vertebrates may present the phenotype due to a defect in melanin synthesis arising from a gene mutation. To date, about 60 different mutations were isolated in many different species of vertebrates.

In most domestic animals, albinism is caused by recessive autosomal or X-linked inheritance, except for the dominant autosomal gene in horses, in which the homozygous form is lethal. Total or complete albinism is described in cats (Turner et al., 1981) and Suffolk sheep (Rowett \& Fleet, 1993). In humans and mice, the C locus was determined as the structural locus for the tyrosinase gene (Tobita-Teramoto et al., 2000).

In the chicken, there are different mutations, resulting in different degrees of depigmentation, and consequently several types of albinism. According to Smith Jr. (1990), there are two general types of pigments in chickens : melanin and carotenoids. Melanin (a natural pigment) plays a major role in the color of feathers, skin, shanks, beak, and eyes, while carotenoids (xanthophyll) are responsible for the yellow color of skin, fat and egg yolk. These two types of pigment can interact with each other and/or other cell types to produce a variety of shank and eye colors, as well as different feather shine levels.

The inheritance of pinkeye was first described by Warren (1940) in White Plymouth Rock chickens, indicating that pinkeye was due to an autosomal recessive gene (pk). Roberts et al. (1952) studied a "redeye" mutation, which is a recessive autosomal gene, and is less viable than dark-eye in the chicken. Both mutations cause sight impairment. 
Braumbaugh et al. (1983) reported three types of albinism at the multiple allelic " $\mathrm{C}$ " locus in the chicken: " $\mathrm{C}^{+}$", which allows full pigmentation; " $\mathrm{C}$ " which is recessive to wild type, but dominant to albinism; and "ca", which is the most recessive allele.

The sex-linked genes for imperfect albinism in chickens are designated as: $\mathrm{S}^{\mathrm{al}-\mathrm{s}}, \mathrm{s}^{\mathrm{al}-\mathrm{c}}$, and $\mathrm{S}^{*} \mathrm{ALS}$. They were analyzed as to their general genetic aspects (Silversides \& Crawford, 1990), neonatal effects (Silversides \& Crawford 1991), and effects on egg production (Silversides and Crawford 1991, Hsu et al., 1994, Hsu et al., 1996), mortality (Silversides et al 1992), early egg production (Silversides et al., 1993), metabolism (Santos \& Silversides, 1996a; 1996b), and sex differentiation (Santos \& Silversides, 1996c).

The study reported in this paper was developed to obtain further information on the mode of inheritance of a mutation that produces white feathers and pink eyes in a flock of free-range Brazilian chicken.

\section{MATERIAL AND METHODS}

The albino mutant chickens were obtained from a private farm located near Universidade Estadual Paulista (UNESP), Botucatu campus, São Paulo, Brazil.

Birds were housed at the University, where they kept for 4 generations. All studied individuals derived from two normal black males (Male 1 and 311 in the tables), which resulted from breeding an albino male to a black female.

According to the information provided by the farmer, the flock had experienced a process of inbreeding for many years, without any control.

The albino birds presented translucent red eyes with no evidence of any pigmentation. Their feathers were completely white and their eyes were pink (Figure 1). In order to prevent mortality, favorable environmental conditions were provided. For instance, they were maintained in a poultry house with limited space to allow them to find food and water. Adult birds were

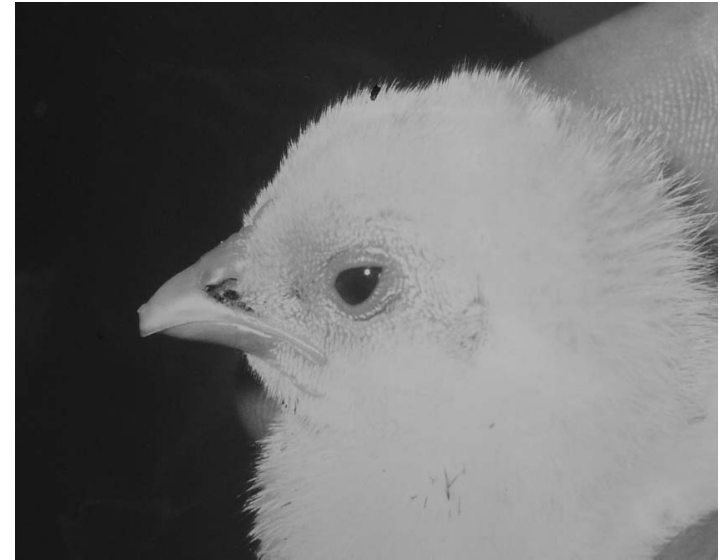

Figure 1 - The albino kid chicken which original animal possess translucid red eye and white feathers.

housed in individual layer cages and submitted to natural insemination.

The methodology consisted in determining albinism ratios involving albinism (Table 1 to 4). During the study, different sets of matings were performed, involving crossing heterozygous individuals; test crossing; and test for sex-linked inheritance.

\section{RESULTS AND DISCUSSION}

Matings between normal individuals (black plumage and eyes) were carried out to determine the mode of inheritance, e.g. Male 1 was mated to seven females $(301,302,304,306,307,308$, and 321) (Table 1), and male 311 was mated to females 305 and 307 (Table 2).

Out of the 144 offspring 44 were pink-eyed albinos and 100 were completely black. According to the hypothesis of recessive autosomal inheritance locus, this result indicate that males and females were heterozygous for autosomal albinism. The expected values of 108 (black) to 38 (albino pink-eyed) was consistent with the expected $3: 1$ segregation ratio. However, sex-linked loci also would give a 3:1 segregation ratio. Matings used to determine the

\begin{tabular}{|c|c|c|c|c|c|}
\hline Mating type (Cc X Cc) & $\begin{array}{l}\text { Feather } \\
\text { black feather /black eye }\end{array}$ & $\begin{array}{l}\text { eye color of offspring } \\
\text { albino feather/pink eye }\end{array}$ & Total & expect.ratio & $Q^{2}$ \\
\hline male $1 \times$ female 306 & 09 & 03 & 12 & & \\
\hline male $1 \times$ female 321 & 21 & 13 & 34 & & \\
\hline male $1 \times$ female 302 & 08 & 03 & 11 & & \\
\hline male $1 \times$ female 301 & 27 & 11 & 38 & & \\
\hline male $1 \times$ female 308 & 18 & 04 & 22 & & \\
\hline male $1 \times$ female 307 & 02 & 06 & 08 & & \\
\hline male $1 \times$ female 304 & 10 & 03 & 13 & & \\
\hline male $311 \times$ female 305 & 01 & 01 & 02 & & \\
\hline male $311 \times$ female 307 & 04 & - & 04 & & \\
\hline TOTAL & 100 & 44 & 144 & $3: 1$ & 2,37 \\
\hline
\end{tabular}




\begin{tabular}{|c|c|c|c|c|c|c|}
\hline \multirow[b]{2}{*}{ Mating type (black $X$ albino) } & \multicolumn{3}{|c|}{$\begin{array}{c}\text { Feather and eye color offspring } \\
\text { Test crossing }\end{array}$} & \multirow[b]{2}{*}{ Expected Total } & \multirow[b]{2}{*}{ ratio } & \multirow[b]{2}{*}{$Q^{2}$} \\
\hline & Black feather/black & eye & Albino /pink eye & & & \\
\hline male $1 \times$ female 2 & 15 & & 15 & 30 & & \\
\hline male $1 \times$ female 12 & 14 & & 11 & 25 & & \\
\hline male $1 \times$ female 3 & - & & 02 & 02 & & \\
\hline TOTAL & 29 & & 28 & 57 & $1: 1$ & 0,017 \\
\hline
\end{tabular}

segregation ratio of the test crossing involved Male 1 and three albino females (Table 2). Out of the 57 offspring, 28 were pink-eyed albino and 29 were black. The expected ratio of 28.5 (albino) to 28.5 (black) was consistent with the expected 1:1 segregation ratio. Here, the sex-linked loci would also give a $1: 1$ segregation ratio.

The results of matings involving analyses of sexlinked inheritance are shown in Table 3 and 4 . According to this hypothesis, all males should have been black. However, the occurrence of five and two albino male offspring suggests that the albino phenotype in these chickens is due to autosomal recessive inheritance.

Warren (1933) was the first to describe autosomal recessive albinism mutation in White Wyandotte chickens to which the symbol "a" was given. Albino birds presented white feathers and pink eyes. Their sight was impaired, making it difficult for birds to find food and water. The crosses used by Warren indicated that those traits are due to separated alleles.

Mueller \& Hutt (1941) found imperfect albinism in Barred Plymouth Rock chickens caused by a sex-linked recessive gene (al). Affected birds present "ghost barring " in their feathers, because melanin production is low. Their sight is also slightly impaired.
Champion (1958) determined the mode of inheritance of pink-eye condition in White Leghorn chickens as caused by a simple sex-linked recessive gene. It is suggested that this gene is identical to the al gene previously reported by Mueller \& Hutt (1941).

Bitgood \& Smith (1991) suggested a new mutation at the $\mathrm{C}$ locus in White Leghorn chickens showing bright pink eyes, which is characteristic of recessive albinism.

\section{CONCLUSION}

Our data suggest that the absence of melanin in the eyes, skin and feathers of the studied flock of Brazilian free-range chickens is an autosomal recessive mutation. Comparison of this mutation to other autosomal recessive albinism mutations suggests total albinism (total absence of melanin in the skin, feathers, and eyes). The abnormal sight and the difficulty to find food and water by the chickens with the albino mutation described in this paper indicate that this mutation has a semi-lethal effect.

\section{REFERENCES}

Bitgood JJ, Smyth Jr JR. Albinism in white Leghorn chickens. Poultry Science 1991; 70:1861-3.

\begin{tabular}{|c|c|c|c|c|c|c|}
\hline Mating type (Cc X Cc) & m black & f black & $\mathrm{m}$ albino & $f$ albino & not det. & Total \\
\hline male $1 \times$ female 306 & 4 & 5 & 1 & 2 & - & 12 \\
\hline male $1 \times$ female 321 & 7 & 4 & 3 & 6 & 14 & 34 \\
\hline male $1 \times$ female 302 & & & & & 11 & 11 \\
\hline male $1 \times$ female 301 & & & & & 38 & 38 \\
\hline male $1 \times$ female 308 & 8 & 1 & 1 & 1 & 11 & 22 \\
\hline male $1 \times$ female 307 & 2 & & & 2 & 4 & 8 \\
\hline male $1 \times$ female 304 & & 5 & & & 8 & 13 \\
\hline male $311 \times$ female 305 & & & & & 2 & 2 \\
\hline male 311 X female 307 & 3 & & 1 & & & 4 \\
\hline TOTA L & 27 & 17 & 5 & 11 & 86 & 144 \\
\hline
\end{tabular}

$\mathrm{f}=$ female; $\mathrm{m}=$ male; not det.= no determined.

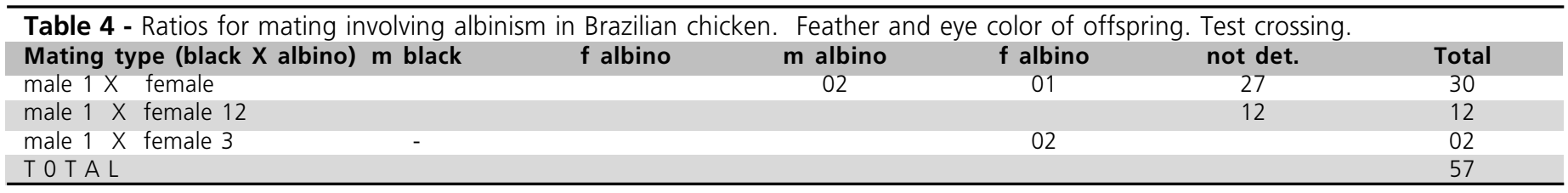


Brumbaugh JA, Bargar TW, Oetting WS. A "new" allel at C pigment locus in the fowl. Journal of Heredity 1983; 74:331-6.

Champion LR. The inheritance of imperfect albinism in the fowl. Michigan Quarterly Bulletin 1958; 41:237-45.

Mueller CD, Hutt FB. Genetics of the fowl - sex linked, imperfect albinism. Journal of Heredity 1941; 32:71-80.

Pearson KE, Nettle HP, Husher CH. A monograph albinism in man. Biometric Series 1911; 6:8-9.

Roberts E, Shaklee WE, Falls HF. A red-eye mutation - In White Plymouth Rocks. Journal of Heredity 1952; 43:200-4.

Rowett MA, Fleet MR. Albinism in a Suffolk sheep. Journal of Heredity 1993; 84:67-9.

Santos GA, Silversides FG. A method for separating sex-linked imperfect albino ( $\left.{ }^{*} A L S\right)$ and nonalbino embryos before hatch. Poultry Science 1996a; 75:585-8.

Santos GA, Silversides FG. Utilization of the sex-linked gene for imperfect albinism ( $S^{*} A L S$ ). 1. Effect of early weight loss on chicken metabolism. Poultry Science 1996b; 75:1455-62.

Santos GA, Silversides FG. Utilization of the Sex-Linked Gene for Imperfect Albinism ( ${ }^{*} A L S$ ) 2. Yolk sac lipid utilization. Poultry Science 1996c; 75:1455-62.

Silversides FG, Crawford RD. Effects of imperfect albinism ( $\mathrm{s}^{\text {al-s}}$ ) on egg production in two lines of chickens. Poultry Science 1991; 70:702-8.

Silversides FG, Crawford RD. Genetic aspects of a new mutation ( $\mathrm{s}^{\text {al- }}$ s) to sex-linked imperfect albinism ( $s^{\text {al-s}}$ ) in chickens. Genetics Selection Evolution 1990; 22:447-55.

Silversides FG, Crawford RD. Phenotypic, embryonic, and neonatal effects of a gene for Imperfect Albinism ( $\mathrm{s}^{\text {al-s}}$ ) in chickens. Poultry Science 1991; 70:1306-13.

Silversides FG, Mérat P, Coquerelle G. Differential environmental effects on lesions, early growth, and mortality of imperfect albino $\left(\mathrm{s}^{\mathrm{al}-\mathrm{c}}\right)$ chicks. Poultry Science 1992; 71:813-20.

Silversides FG, Williams J, Mérat P. Effects of sex-linked imperfect albinism in the chicken ( $\mathrm{sal}^{\mathrm{al}-\mathrm{c}}$ ) on plasma luteinising hormone concentrations and early egg production. British Poultry Science 1993; 34:1011-19.

Smyth-Jr JR. Genetics of plumage, skin and eye pigmentation in chickens:109-67. In: Crawford RD, editor. Poultry breeding and genetics. Amsterdam: Elsevier; 1990.

Su $H$, Silversides FG, Villeneuve P. Effects of sex-linked imperfect albinism ( $\mathrm{s}^{\mathrm{al}-\mathrm{s}}$ ) in the chicken on the relationships of plasma concentrations of progesterone and 17-beta-estradiol with egg production. Poultry Science 1996; 75:13-9.

Su $H$, Silversides FG, Villeneuve P. Production and quality of eggs from sex-linked imperfect albino $\left(\mathrm{s}^{\mathrm{al}-\mathrm{s}}\right)$ and nonalbino(s+) hens kept under commercial conditions. Poultry Science 1994; 73:1813-21.

Tobita-Teramoto T, Jang GY, Kino K, Salter DW, Brumbaugh J, AkiyamaT. Autossomal albino chicken mutation $\left(\mathrm{c}^{\mathrm{a}} / \mathrm{C}^{\mathrm{a}}\right)$ deletes hexanucleotide (-D-GACTGG817) at a copper-binding site of the tirosinase gene. Poultry Science 2000; 79:46-50.

Turner P, Robinson R, Dite CE. Blue-eyed albino: a new albino allele in the domestic cat. Genetica 1981; 56:71-73.

Warren DC. Inheritance of albinism in the domestic fowl. Journal of Heredity 1933; 24:379-83.

Warren DC. Inheritance of pinkeye in the fowl. Journal of Heredity 1940; 31:291-2. 